\title{
ОСОБЕННОСТИ ВНЕШНЕЙ ПОЛИТИКИ ИМПЕРАТОРА МАГНА МАКСИМА В 383-387 ГГ.
}

\section{FEATURES OF FOREIGN POLICY OF EMPEROR MAGNUS MAXIMUS \\ IN 383-387}

\section{S. Yartsev \\ M. Ryabtseva}

Summary: The article is devoted to the peculiarities of Magnus Maximus' foreign policy. Commander of the British garrisons and former colleague of Theodosius I, was proclaimed Emperor by the troops and established his authority in Britain, Spain and Gaul in 383. The study thoroughly analyzes reports from a large group of written sources, including the New History of Zosimus, the letters of Ambrose of Mediolan, the Church stories of Rufinus, Socrates and Sozomen. According to the authors, the foreign policy of Magnus Maximus after his approval in Gaul, first of all, was aimed at finding as soon as possible barbarian allies in the upcoming struggle for power. It was this factor that acquired a dominant role in the confrontation between Maximus and Theodosius I and Valentinian II. At the same time, the most acute struggle of the rival emperors was for the federates of Pannonia, who lost their contractual relations with the Empire after the death of Gratian. The importance of relations with these barbarians for Maximus lay in the fact that, because of their strategic location, they could easily block all routes to the west and detain Theodosius I for a long time. The eventual conversion of these barbarians to the side of Valentinian II explained Maximus' refusal to attack the Apennine Peninsula in 383-384. In the future, the usurper suffered a number of failures associated with an attempt to raise a mutiny among the Pannonian federates with the help of the Goths of the Northern Black Sea region and even his own military units specially sent by Maximus to this province. The rashness of his actions and the haste with which Magnus Maximus acted were the main reasons for his defeats, which eventually cost him his life.

Keywords: Roman Empire, Emperor Maximus, Emperor Theodosius I, Emperor Gratian, Emperor Valentinian II, Pannonia, Goths, Huns, federates.
Ярцев Сергей Владимирович

Д.и.н., доцент, Тульский государственный педагогический университет им Л.Н. Толстого

s-yartsev@yandex.ru

Рябцева Марина Леонидовна

К.и.н., Белгородский государственный национальный исследовательский университет ryabtseva@bsu.edu.ru

Аннотация: Статья посвящена особенностям внешней политики Магна Максима. Командующий британскими гарнизонами и бывший сослуживец Феодосия I, был провозглашен войсками императором и установил свою власть в Британии, Испании и Галлии в 383 году. В исследовании тщательно проанализированы сообщения большой группы письменных источников, В том числе, Новой Истории Зосима, писем Амвросия Медиоланского, Церковных историй Руфина, Сократа и Созомена, которые касаются периода правления узурпатора. По мнению авторов, внешняя политика Магна Максима после утверждения его в Галлии, в первую очередь, была направлена на скорейший поиск варварских союзников в предстоящей схватке за власть. В противостоянии Максима с Феодосием I и Валентинианом II, именно данный фактор приобрел главенствующую роль. При этом наиболее острая борьба императоров - соперников, развернулась за федератов Паннонии, лишившихся договорных отношений с империей после гибели Грациана. Важность отношений с указанными варварами для Максима заключалась в том, что они, из-за своего стратегического местоположения, могли легко заблокировать все пути на запад и надолго задержать Феодосия І. Переходом, в конечном итоге, данных варваров на сторону Валентиниана II, объясняется отказ Максима от нападения на Апеннинский полуостров в 383-384 гг. В дальнейшем узурпатор потерпел еще ряд неудач, связанных с попыткой поднять мятеж среди федератов Паннонии при помощи готов Северного Причерноморья и даже собственных воинских подразделений, специально посланных Максимом в эту провинцию. Непродуманность действий и спешка, с которой действовал Магн Максим, стали основными причинами его поражений, в итоге стоивших ему жизни.

Ключевые слова: Римская империя, император Максим, император Феодосий I, император Грациан, император Валентиниан II, Паннония, готы, гунны, федераты.

Феодосия I [5, с. 185, прим. 2], Магн Максим. Войска провозгласили его императором, «вручив ему пурпур и корону» [Zosim., IV, 35, 4; Paneg., 12, 23,3; Oros., VII, 34, 9; Socr., V, 11; Soz., VII, 13; Aur. Victor. Epit., 47, 7]. Вскоре, переправившись через Ла-Манш, Максим смог разбить Грациана в битве в окрестностях современного Парижа [5, с. 185, прим 3]. Однако данная победа была достигнута за счет предательства собственных войск западного императора. Измена стала закономерным результатом негативного отношения армии к Грациану. Главными причинами этого обычно называют излишнее доверие императора 
К «придворным, погрязшим во взяточничестве» [Zosim., IV, 35, 2; Aur. Victor. Epit., 47, 6], и щедрую оплату неких аланских дезертиров, получивших престижную службу в гвардии, из-за чего Грациан стал пренебрегать остальными солдатами [Zosim., IV, 35, 2]. Последнее обстоятельство, послужило провоцирующим фактором в наибольшей степени. Император, по-видимому, действительно перестал оказывать знаки внимания своим воинам, так как «благодаря неисчислимому золоту», «перевел к себе нескольких алан», которых он «предпочел старому и римскому воину, и настолько взял варваров в свою свиту и почти в свою дружбу, что иногда тем же обычаем совершал прогулку» [Aur. Victor. Epit., 47, 6]. Считается, что данные аланы могли быть из числа варваров-федератов, расселенных Грацианом в 380 г. в Паннонии [7, с. 65]. Обязанные своим возвышением императору, они, безусловно, демонстрировали особую преданность и поэтому среди императорского окружения вызывали у Грациана наибольшее доверие.

Однако, такое изменившееся отношение к старым римским воинам, было не единственной причиной, способствующей падению императора. Вскоре к этому добавилась негативная реакция римской аристократии на действия Грациана, направленные против традиционных верований, включая вынос алтаря Победы из здания сената и отказ от звания великого понтифика [Zosim., IV, 36, 5] [1, с. 576, прим. 750; 21, р. 36-40; 18, р. 549-552]. В какой-то момент франкские военачальники Грациана решили, что им гораздо выгодней остаться при малолетнем Валентиниане II, чем терпеть над собой Грациана, потерявшего всякое уважение и влияние в армии [1, с. 214-215]. Сам же император, бежавший «в Альпы с тремястами конных воинов», решил двигаться дальше в «Рецию, Норик, Паннонию и Верхнюю Мёзию» [Zosim., IV, 35, 5], под защиту своих федератов, расселенных в этих местах в 380 году. Трудно сказать, как развернулись бы события, если Грациану удалось все же добраться до верных ему союзников. Однако бывший магистр конницы Андрагафий отправленный Максимом в погоню за императором, догнал его в Лионе и убил [Zosim., IV, 35, 6; Rufin., II, 14; Socr., V, 11; Soz., VII, 13].

Не теряя времени, Максим отправляет послов к соправителю Грациана - Валентиниану II [Ambr. Ep., 24; Rufin., I, 15; Socr., V, 11; Soz., VII, 13] и к Феодосию I, с требованием признать его императором [Zosim., IV, 37, 2-3]. В сложившейся ситуации, пока Феодосий I и будучи еще двенадцатилетний подросток - император Валентиниан II, тянули время, в конечном итоге, согласившись не только на требования узурпатора, но и на титул августа для сына Максима, верные законной власти войска заблокировали альпийские перевалы, оставив узурпатора на территории к северу от Альп [3, с. 420-421]. Так как Валентиниан II, в ответ на приглашение Максима явиться к нему в Триру, чтобы якобы править вместе «как отец и сын» [Ambr. Ep., 24, 7], ответил отказом, напряженная си- туация, продолжала сохраняться в империи, по крайней мере, до лета 384 г. [3, с. 421; 5, с. 186, прим. 2].

Любопытно, но именно в это время у Валентиниана II резко обострились отношения с варварами, что в сложившейся ситуации, вряд ли могло быть простой случайностью. Вполне вероятно, что уже в 383 году убийца Грациана - Андрагафий или его люди отправились в сторону Паннонии к варварам-федератам Алафея и Сафрака с предложением перезаключения союза с новым императором Магном Максимом. По нашему мнению, только этим обстоятельством можно объяснить странный военный поход, предпринятый в 384 году паннонскими федератами в Галлию, находившуюся в это время под властью узурпатора. При этом подошедшие с востока варвары, почему-то, создали серьезные проблемы не Максиму, а Валентиниану II. Это следует из слов Амвросия Медиоланского, сообщившим, что в то время, когда Максим угрожал вторжением в «Италию с отрядами варваров, Валентиниан гуннов и аланов, приближающихся к Галлии, обратил назад через земли Аламаннии» [Ambr. Ep., 24, 8] [8, с. 82]. Обычно этих упомянутых гуннов и аланов, справедливо отождествляют с федератами Грациана из Паннонии $[9$, с. $42 ; 15$, р. $37 ; 8$, с. 82$]$.

Однако мы не можем согласиться с утверждением, что данный варварский поход имел своей целью выступление против галльского узурпатора Магна Максима [8, с. 82]. В это время против последнего, никаких военных операций не предпринималось, а действия противников ограничивались караульной службой «солдат обеих сторон, охранявших горные перевалы» [Ambr. Ep., 24, 7]. К тому же, если бы варвары, действительно призвались против Максима, то их не нужно было отправлять обратно, да еще и на полпути к конечной цели экспедиции. Тем более, если считать, что окружение Валентиниана II, затягиванием переговоров с Максимом, специально выигрывало время для своих войск, которые, в данное время, брали под контроль проходы через Альпы, ожидая нападения с севера [3, с. 421]. Кроме того, если причиной появления варварской армии на границе Галлии, являлась бы угроза, исходившая от Максима, то уже само продвижение федератов в западном направлении, как и последующее их возвращение назад, должны были спровоцировать узурпатора на нападение на Италию. Такой вариант событий мог произойти, независимо от уровня договоренности между противоборствующими сторонами, ведь через несколько лет, именно подобные внешние обстоятельства сыграли свою решающую роль в походе Максима на Италию [10, с. 48]. Сейчас же, Феодосий I, не имел возможностей оказать реальную помощь Валентиниану II, поэтому в отношениях с Максимом он ограничивался лишь демонстрацией своей силы [Chron. Gall., 646; Socr., V, 12] [20, p. 267-301; 10, с. 48]. Разумеется, узурпатор это понимал и поэтому по отношению к Риму был настроен решительно. Тем не менее, похода Максима против Валентиниана II, в первые 
годы после утверждения узурпатора в Галлии, не случилось. По нашему мнению, логичнее предположить, что, скорее всего, федераты шли на помощь к Максиму, так как предложенные условия договора нового императора, оказались предпочтительнее для варваров. Представляя огромную опасность для Италии, по пути они были перехвачены Валентинианом II, после чего, перешли на его сторону. По-видимому, именно этим обстоятельством и были сорваны планы Максима нападения на полуостров. Учитывая то, что уже в 384 году против ютунгов напавших на Рецию «был призван гунн» [Ambr. Ер., 24, 8], федератам были предложены довольно выгодные условия возобновленного договора. По этой причине, помимо войны с ютунгами, к военным действиям паннонских варваров, уже в качестве союзников Валентиниана II, возможно, следует отнести и не совсем мирное их возвращение через «Аламанию» [Ambr. Ep., 24, 8]. Также, вероятно, что именно с данным рейдом следует связать слова Амвросия о военачальнике Валентиниана II - Бавтоне, который заставил «варваров, решать спор с варварами» [Ambr. Ер., 24, 8]. Это подтверждает и последующий текст епископа о гуннах «сокрушивших Аламанию» [Ambr. Ep., 24, 8].

Заметим, что наше предположение о том, что бывшие федераты погибшего Грациана шли из Паннонии в Галлию, будучи привлеченные предложениями Максима, хорошо согласуется с особенностями внешней политики узурпатора, которую он стал проводить по отношению к Барбарикуму. Конечно, в ней трудно разглядеть антиварварскую «национальную реакцию» с опорой на римские войска [16, р. 256], даже, несмотря на то, что Максим наголову разбил пиктов и скоттов в Британии [CIL, XI, 6327] [7, с. 67, прим. 23]. Скорее наоборот, после утверждения в Галлии, его внешняя политика стала проводиться с расчетом на варварскую поддержку и скорейшую вербовку наемников за пределами римских границ. Как верно подметил Е.А. Мехамадиев, именно таким способом, в данное время в Галлии появились отряды франков и аламаннов. Таким образом, узурпатору довольно быстро удалось создать угрозу Италии варварскими «пешими и конными отрядами с той стороны пограничного вала», оплачиваемыми «из налогов провинциалов» [Ambr. Ep., $24,8][7$, с. 67].

Учитывая, что Максиму удалось подбить на выступление против Феодосия I, готов Северного Причерноморья [Zosim., IV, 39, 5], он не мог оставить без внимания находившихся гораздо ближе к Галлии федератов Паннонии, и тем более, варваров живших сразу за Рейном. Особенно его должны были волновать паннонские федераты, лишившиеся договорных отношений с империей, после гибели Грациана. Здесь Максиму необходимо было действовать по возможности быстро, опережая Валентиниана II, который сам стремился вернуть варваров под юрисдикцию Рима. Скорее всего, именно данное обстоятельство, способствовало оперативному переходу на- емных отрядов и союзных варварских армий на службу к Максиму. Дезертировавший из Италии и перебежавший к Максиму уже в 383 году, магистр пехоты франкского происхождения Меробавд, вероятно ориентировался именно на такое изменение римской политики по отношению к варварам. Правда, перебежчик, получивший от Валентиниана II консульское звание [14, р. 163], действительно мог оказаться изменником, подготавливающим вражеское вторжение в Галлию. В таком случае за содеянные деяния, он справедливо поплатился своей жизнью [19, s. 101-105; 7, с. 65-66]. Косвенно на факт предательства может указывать то обстоятельство, что вскоре, часть тех же франков, по какой-то причине оказалась в лагере врагов Максима. Поэтому, не случайно, узурпатор, в конечном итоге проигравший в ряде сражений, в том числе «был побежден франками» [Ambr. Ep., 40, 23].

В связи со всем вышесказанным, вряд ли, можно считать верным предположение о значительной самостоятельности паннонских федератов, которые сами решали, с кем им в данный момент воевать, а с кем нет [6, с. 92]. Амвросий, действительно утверждает, что подошедшие варвары, победив всех недругов, готовы были теперь напасть уже и на самого Максима «угрожая вторжением в Галлию», однако «были принуждены оставить эти завоевания», так как они противоречили миролюбивым планам императора Валентиниана II [Ambr. Ep., 24, 8]. По нашему мнению, данный текст, включая и ту часть, в которой говорится, что Валентиниан II «своим золотом, купил мир» для Максима, необходимо рассматривать в контексте особенностей всей речи епископа, обращенной к узурпатору. Напомним, что в ней обличались несправедливые и враждебные действия Максима, на фоне миролюбивой и мудрой политики Валентиниана II. Поэтому обычная, в таких случаях, плата федератам за военную кампанию, в данном контексте могла быть специально представлена Амвросием, в качестве добросердечной акции молодого императора, призванной спасти Максима от неминуемого нападения враждебных полчищ.

Конечно, первые неудачи Максима по смещению «юного Валентиниана по возможности на всей территории империи», не остановили узурпатора, который «приготовился перейти Альпы и продвигаться вперед по Италии» [Zosim., IV, 42, 1-2]. Но, в таком случае, ему необходимо было заручиться поддержкой наиболее влиятельных сил римского общества. Возможно, именно с этим связано его демонстративное участие в церковном синоде, осудившем на казнь за склонность к дуализму, некоего Присциллиана. Впрочем, к такому трагическому варианту развития событий, могло привести и довольно серьезное отношение к религиозным обязанностям нового императора [4, с. 311]. Далее, в ответ на издание Валентинианом II в 386 году эдикта о терпимости по отношению к арианам, Максим пишет письмо в Рим [4, с. 305], в котором говорит о недопустимости преследования 
ортодоксальных христиан и достаточно мягко увещевает соправителя, вернуться на истинный путь своего отца. Тем самым Максим почти добивается того, что очень многие представители римской знати - приверженцы никейского христианства, почувствовав исходящую от узурпатора поддержку, переходят на его сторону [11, с. 60-61]. Однако, позже часть этих людей, вновь отворачивается от Максима. По словам Амвросия, буквально за несколько дней до похода на Италию, узурпатор, в ответ на сожженную в Риме синагогу, отправил туда свой очередной указ, призванный защитить общественный порядок. По этой причине «Максим был оставлен» римлянами, так как «народ христианский сказал: «Ничего хорошего этого человека не ждет»» [Ambr. Ep., 40, 23 ].

Тем не менее, приоритетной для Максима, продолжала оставаться именно варварская поддержка, в которой особенно выделялась позиция федератов Паннонии. Дело в том, что данные воинские подразделения, из-за своего стратегического местоположения, могли легко заблокировать все пути на запад и надолго задержать Феодосия І. Поэтому на этом направлении своей политики, с целью достижения положительного результата, Максим прикладывал неимоверные усилия, не останавливаясь даже перед откровенным обманом на государственном уровне. Так, Домнина, прибывшего в Тревиру с посольством от Валентиниана II, с целью поиска «более надежного мира» [Zosim., IV, 42, 3], Максим, не только принял с особым почетом и одарил щедрыми подарками, но и «отослал часть своей армии на помощь Валентиниану против варваров, угрожавших Паннонии, которая ему принадлежала» [Zosim., IV, 42, 5]. Что это были за варвары, создавшие угрозу римской провинции, нам не известно. В законе 386 года, действительно, говорится о рабочих рудников, отказывающихся работать из-за угрозы нападения врагов [CTh., I, 32, 5]. Возможно, опасная ситуация возникла в связи с усилением давления варварского мира на приграничные римские территории. В любом случае, истинные причины узурпатора, были далеки от стремления оказать реальную помощь соправителю.

В этой связи, учитывая наличие паннонской зоны интересов Максима, не исключено, что именно разгром войсками Феодосия I, подошедшего из Северного Причерноморья воинства Одотея [12, с. 107-118], послужил главной причиной отправки узурпатором своих отрядов в эту провинцию. Возможно еще варвары Одотея, проникнув под видом беженцев на территорию империи, должны были начать восстание с участием федератов Паннонии. После неудачи этой попытки, Максим не оставлял надежды, что ушедшие на восток его отряды, все же смогут в нужный момент поднять мятеж в войсках федератов и блокировать Феодосию I все пути на запад. Ускориться с выполнением данной задачи, его вынуждали известия о заключении Феодосием I в 387 году мира с Персией, после которого положение узур- патора осложнилось. Теперь, несмотря на то, что Константинополь пожертвовал большей частью Армении, Феодосий I мог легко перебросить войска с востока на запад и направить их против Максима [10, с. 48]. Поэтому восстание федератов в Паннонии 387 года, о котором пишет А. Пиганьоль [17, р. 248], вполне могло быть результатом именно коварных замыслов Максима. Правда, утверждать о полном уничтожении римской цивилизации в этой провинции в ходе этого восстания, мы считаем преждевременным. Также сомнительным выглядит предположение, что выступление федератов Паннонии могло состояться ранее 387 года, по причине стремления варваров захватить и отторгнуть от империи данную территорию [1, с. 214]. Такое предполагаемое поведение федератов не находит своего логического объяснения. Напомним, что чем основательнее обустраивались варвары в пределах Римской империи, тем меньше они были заинтересованы в ее разрушении [2, с. 25]. То, что волнения среди паннонских федератов были связаны с отсылкой туда войск Максима, также косвенно подтверждает, взятие именно в данное время, его комитом Андрагафием, еще и «всех возможных проходов через Альпы и переправ через реки» [Oros., VII, 35, 3]. Очевидно, что вместе с паннонским мятежом, это должно было создать непреодолимое препятствие для продвижения войск Феодосия I на запад.

В связи с достигнутыми успехами по подготовке вторжения, в 387 году армия Максима неожиданно перешла Альпы и вступила на земли Италии. Валентиниан II был поражен стремительностью появления узурпатора на Апеннинском полуострове. Вместе с матерью Юстиной и сестрой Галлой, ему удалось бежать на корабле к Феодосию [Zosim., IV, 43, 1; Socr., V, 11-12; Soz., VII, 13-14; Rufin., I, 16]. Вскоре, благодаря хитрым интригам Юстины, не так давно овдовевший Феодосий, женился на Галле, пообещав объявление войны Максиму и возвращение Валентиниану II всех владений его отца [Zosim., IV, 44, 4]. Таким образом, гражданская война в империи становилась неизбежной. В этой связи, восстание федератов Паннонии и возможный массовый переход их на сторону Максима, превратились в серьезную угрозу предстоящему походу Феодосия I на запад [Zosim., IV, 45, 3]. Поэтому когда императору сообщили, что некоторые федераты - «варвары, вступившие в римские легионы, помышляли об измене из-за великих наград, обещанных Максимом» [Zosim., IV, 45, 3], Феодосий бросил против них все имеющиеся у него силы. Осознав, что они «обнаружены, варвары, тем не менее, бежали в топи Македонии и скрылись в зарослях. Их обнаружили там и преследовали всеми возможными средствами. Почти все из них были убиты» [Zosim., IV, 45, 3; Eunap., 58].

Возможно, именно неудача в Паннонии вынудила Андрагафия оставить горные перевалы и попытаться «застать врасплох врага морским рейдом» [Oros., VII, 35, 3]. Комит Максима даже попытался поймать в Иониче- 
ском море Валентиниана II, который в действительности пересек «пролив задолго до этого» [Zosim., IV, 46, 1]. Несогласованные действия противника, позволили Феодосию I летом 388 года, без задержек пересечь «Паннонию и Апеннины и атаковать войско Максима, пока оно не ожидало нападения» [Zosim., IV, 46, 2]. В конечном итоге Максим был убит, как и впоследствии и его сын, оставленный отцом в Галлии. Узнав об этом покончил жизнь самоубийством «нырнув в воду» и Андрагафий [Zosim., IV, 46, 2-3, 47, 1; Cons. Const., 1, 245; Hydat. Chron., 2, 15; Paneg. 12, 444; Oros., VII, 35, 4-5] [21, p. 40-43, 61-64; 3, c. $421 ; 13$, p. $107 ; 10$, c. 49].

Таким образом, внешняя политика Магна Максима, после его утверждения в Галлии, безусловно, была направлена на скорейший поиск варварских союзников в предстоящей схватке за власть. В противостоянии Максима с Феодосием I и Валентинианом II, именно данный фактор приобрел главенствующую роль. При этом наиболее острая борьба императоров - соперников, развернулась за федератов Паннонии, лишившихся дого- ворных отношений с империей после гибели Грациана. Важность отношений с данными варварами для Максима заключалась в том, что они, из-за своего стратегического местоположения, могли легко заблокировать все пути на запад и надолго задержать Феодосия І. В связи с тем, что предложенные условия договора нового императора, оказались предпочтительнее для федератов Паннонии, вначале они решили поддержать Максима. Однако, представляя огромную опасность для Италии, по пути в Галлию они были перехвачены Валентинианом II, после чего, перешли на его сторону. Безусловно, именно данным обстоятельством объясняется отказ Максима от нападения на Апеннинский полуостров в 383-384 гг. В дальнейшем узурпатор потерпел еще ряд неудач, связанных с попыткой поднять мятеж среди федератов Паннонии при помощи готов Северного Причерноморья и даже собственных воинских подразделений, специально посланных Максимом в эту провинцию. Непродуманность действий и спешка, с которой действовал Магн Максим, стали основными причинами его поражений, в итоге стоивших ему жизни.

\section{ЛИТЕРАТУРА}

1. Банников А.В., Морозов М.А. Византийская армия (IV-XII вB.). - СПб.: Евразия, 2017. - 688 с.

2. Буданова В.П. Парадоксы варварства в историческом контексте // Цивилизация и варварство: парадоксы победы цивилизации над варварством. М.: ИВИ РАН, 2013. - Вып. ІІ. - С. 12-41.

3. Голдсуорти А. Падение Запада. Медленная смерть Римской империи. -М.: АСТ, 2014. - 733 с.

4. Грант М. Римские императоры: Биографический справочник правителей Римской империи 31 г. до н. э. - 476 г. н. э. - М.: ТЕРРА; Книжный клуб, 1998. $400 \mathrm{c}$.

5. Зосим. Новая история / Перевод, комментарии, указатели Н.Н. Болгова. - Белгород: Изд-во БелГУ, 2010. - 344 с.

6. Ивик 0., Ключников В. Гунны. - М.: Ломоносовъ, 2018. - 344 с.

7. Мехамадиев Е.А. Войсковое подразделение Angrivarii, «Веронский список» (Laterculus Veronensis) и вторжение Алариха в Италию: к вопросу о датировке позднеримской военной надписи из Аугсбурга // Проблемы истории, филологии, культуры. - 2014. - № 2(44). - С. 57-74.

8. Мехамадиев Е.А. Синезий Киренский и войсковое подразделение «Уннигарды»: к вопросу о положении готов и гуннов в западной Римской империи в последней четверти IV в. // Вестник Нижегородского университета им. Н.И. Лобачевского. - 2015. - №1. - С. 78-86.

9. Томпсон Э.А. Гунны. Грозные воины степей. - М.: ЗАО Центрполиграф, 2008. - 256 с.

10. Хьюджес Й. Стилихон. Вандал, который спас Рим. - М.: Изд-во «Клио», 2017. - 352 с.

11. Чернявский Н.Ф. Император Феодосий Великий и его царствование в церковно - историческом отношении. - Сергиев Посад: Типография Свято-Троицкой Сергиевой Лавры, 1913. - 708 с.

12. Ярцев С.В. Обстоятельства похода готов Одотея на Римскую империю // Кондаковские чтения. Античность - Византия - Древняя Русь / Под ред. Н.Н. Болгова. - Белгород: Изд-во БелГУ, 2019. - Вып. VI. - С. $107-118$.

13. Curran J. From Jovian to Theodosius / Ed. A. Cameron, \& P. Garnsey // The Cambridge Ancient History XIII: The Late Empire, A.D. 337 - 425. - Cambridge: Cambridge University Press, 1997. - P. 78-110.

14. De Rossi G.B. Inscriptiones Christianae Urbis Romae septimo saeculo antiquiores G.B. de Rossi (ed.). - Romae: Ex Officina Libraria Pontificia, 1861. - Vol. I. - 533 p.

15. Gračanin H. The Huns and South Pannonia // Byzantinoslavica. - 2006. - V.64. - P. 29-76.

16. Palanque J.-R. L'empereur Maxime // Les empereurs romaines d'Espagne. Paris: Éditions du Centre national de la recherche scientifique. - 1965. - P. 255-268.

17. Piganiol A. L'Empire Chretien (325-395). - P.: Presses universitaires de France, 1972. - 501 p.

18. Potter D. The Roman Empire at Bay, AD 180-395. - L.; N.Y.: Routledge, 2004. - 762 p.

19. Rodgers B.S. Merobaudes and Maximus in Gaul // Historia. Zeitschrift für Alte Geschichte Band. - 1981. - XXX. - Hft. 1. - S. 82-105.

20. Vega D. I rapporti fra Magno Massimo, Teodosio e Valentiniano II nel 383-384 // Athenaeum: Studi di letteratura e Storia dell'antichità. - 1975. - №53. P. 267-301.

21. Williams S., Friell G. Theodosius: The Empire at Bay. - L.: Batsford, 1994. - 238 p.

( Ярцев Сергей Владимирович (s-yartsev@yandex.ru), Рябцева Марина Леонидовна (ryabtseva@bsu.edu.ru).

Журнал «Современная наука: актуальные проблемы теории и практики» 